\title{
KAJIAN TEORITIS PEMANFAATAN APLIKASI ANGKUTAN BERBASIS ONLINE DITINJAU DARI UNDANG-UNDANG NO.8 TAHUN 1999 TENTANG PERLINDUNGAN KONSUMEN BERKAITAN DENGAN UNDANG-UNDANG NO. 11 TAHUN 2008 TENTANG INFORMASI TRANSAKSI ELEKTRONIK
}

\author{
Sri Siti Munalar \\ Fakultas Hukum, Universitas Pamulang \\ Email : morteza_muthhohari@yahoo.com
}

Received: - /Revised: - / Accepted: Ags 2018

\begin{abstract}
Wujud mencakup segala hal, mulai dari Dzat Suci (Ilahi), realitasrealitas abstrak dan material, baik substansi maupun aksiden, baik esensi maupun keadaan selalu mengalami gerak substansi, demikin pula dengan species manusia, sebagai bagian dari wujud yang dianugerahi akal budi senantiasa mengalami gerak substansi (Substantion Motion atau Al-Harakat al-Jawhariyyah).Manusia bagian dari wujud sadar ataupun tidak ia akan terus bergerak apakah kepada kemajuan atau kemunduran tergantung subjek manusia itu sendiri dan juga dipengaruhi lingkungan sekitarnya. Gerak tadi menjadi apa yang disebut sebagai perubahan. Pertumbuhan penduduk yang begitu pesat, merupakan bagian dari perubahan, sementara tidak berbanding lurus dengan lapangan pekerjaan yang tersedia maka peluang usaha yng sekaligus juga menjawab keinginan masyarakat dalam usaha pemenuhan kebutuhannya baik dari pihak pebisnis atau owner maupun bagi masyarakat pengguna jasa bisnis tersebut dalam sektor informal, munculah fenomena angkutan berbasis online sebagai sarana pengisi kekosongan yang belum mendapat perhatian pemerintah sebelumnya, seperti Go-Jek, Grabbike dan Uber. Adapun usaha/bisnis tersebut berlandaskan kepada pasal 1338 KUHPerdata jo pasal 1320 KUHPerdata, Di dalam praktek bahwa unsur kesepakatan menjadi penting terlaksananya sebuah perikatan dan pelaksanaan perjanjian sebab sudah menjadi undang-undang bagi yang membuatnya, akan tetapi dalam bisnis online dikarenakan tidak adanya face to face antara yang menawarkan barang dan atau jasa (Pengusaha/owner) dengan yang menghendaki barang dan atau jasa (Konsumen) adalah peluang kecurangan bagi pihak-pihak yang tidak memiliki itikad baik. Persoalan lainnya adalah tercipta friksi, persaingan antara pebisnis angkutan berbasis online dengan pelaku usaha angkutan konvensional. Diantara owner dengan konsumen terdapat mitra usaha yaitu driver yang juga
\end{abstract}


sebagai konsumen pertama sebab mitra tersebut menggunakan system yang ditawarkan pengusha/owner dimaksud. Fiat Justitia Ruat Coelum.

Kata kunci : Aplikasi Angkutan, Berbasis Online, ITE

\begin{abstract}
Being includes everything, starting from the Divine Essence, abstract and material realities, both substance and accident, both essence and state always experiencing the motion of substance, as well as the human species, as part of the being endowed with reason. substance motion (Substantion Motion or Al-Harakat alJawhariyyah). Man part of conscious form or not he will continue to move whether to progress or decline depending on the human subject itself and also influenced by the surrounding environment. This motion became what is called change. The rapid population growth is part of the change, while not directly proportional to the available jobs, business opportunities that also respond to the wishes of the community in an effort to fulfill their needs both from the businessman or owner and for the business service users in the informal sector. the phenomenon of online-based transportation emerged as a means of filling in gaps that had not received the attention of the previous government, such as Go-Jek, Grabbike and Uber. The business / business is based on article 1338 of the Civil Code in conjunction with article 1320 of the Civil Code, in practice that the element of agreement is important in the implementation of an agreement and the implementation of the agreement because it has become a law for those who make it, but in online business because there is no face to face between those who offer goods and or services (Entrepreneurs / owners) with those who want goods and or services (Consumers) are opportunities for cheating for those who do not have 'good faith'. Another problem is the creation of friction, competition between online-based transport businessmen and conventional transport business actors. Among the owners and consumers there are business partners namely drivers who are also the first consumers because the partners use the system offered by the owner / owner. Fiat Justitia Ruat Coelum.
\end{abstract}

Keywords: Transport Application, Online Based, ITE

\title{
PENDAHULUAN
}

Wujud mencakup segala hal, mulai dari Dzat Suci (Ilahi), realitas-realitas abstrak dan material, baik substansi maupun 
aksiden, baik esensi maupun keadaan selalu mengalami gerak substansi ${ }^{1}$, demikin pula dengan species manusia, sebagai bagian dari wujud yang dianugerahi akal budi senantiasa mengalami gerak substansi (Substantion Motion atau Al-Harakat alJawhariyyah). Dijelaskan bahwa gerak adalah perubahan entitas dari satu posisi ke posisi lainnya.Sementara perubahan adalah pergerakan entitas dari satu kondisi ke kondisi lainnya. Jadi, gerak adalah perubahan gradual. Filosof sebelumnya berpandangan bahwa gerak terjadi pada kualitas, kuantitas, posisi, dan tempat. Sementara itu, Sadra berpandangan bahwa perubahan terjadi pada“Substansi dan Aksiden"2.

Manusia bagian dari wujud sadar ataupun tidak ia akan terus bergerak apakah kepada kemajuan atau kemunduran tergantung subjek manusia itu sendiri dan juga dipengaruhi lingkungan sekitarnya. Gerak tadi menjadi apa yang disebut sebagai perubahan. Kemajuan teknologi yang amat pesat telah membawa berbagai macam pengaruh, baik dari dalam maupun dari luar. Pengaruh kemajuan teknologi begitu mudah hadir di tengahtengah kita. Lambat laun tanpa disadari orang telah mengadopsi nilai-nilai baru tersebut.

Go-Jek yang disusul kompetitornya, Grab Bike mengundang banyak perhatian. Telepas dari kontroversinya, startup entrepreneur angkutan berbasis aplikasi online sebagai fenomena bisnis seolah mampu memformalkan profesi tukang ojek konvensional dan memunculkan nilai lebih yang terkandung di dalamnya. Apresiasi terhadap startup entrepreneur tersebut mendapat perhatian positif dari Presiden Joko Widodo dan petinggi

${ }^{1}$ M.T.Mishbah Yazdi,Daras Filsafat Islam: Orientasi ke Filsafat Islam Kontemporer, (Jakarta, Shadra Press), 2010, hlm. 218.

${ }^{2}$ Muhammad Taqi Misbah Yazdi, Âmuzesy-e Falsafeh, (Qom, Nasyr-e Bainal Milal, Cap-e Haftum), 1386 S. , jld. 2, hlm. 285 - 293 
International Monetery Fund (IMF) Christine Legarde. Nadiem Makarim founder Go-Jek telah memberi contoh bagaimana generasi muda Indonesia mampu menuangkan ide kreatifnya dalam menciptakan platform baru untuk mempertemukan secara direct antara ojek dan pelanggan ${ }^{3}$.

Melalui inovasi bisnis yang relative baru ini kita diajak belajar bagaimana sebuah usaha dan perekonomian membutuhkan kebijakan bersifat inklusif. Go-jek menunjukan bagaimana perkembangan teknologi dan inovasi yang diperlukan guna meningkatkan kegiatan bernilai tambah tinggi. Kehadirannya memberi solusi persoalan transportasi khususnya di kota metropolitan seperti Jakarta dan sekitarnya.

\section{Keunggulan Angkutan Berbasis Online}
a. Lebih Terpercaya.
b. Praktis.
c. Tarif murah dan pasti.
d. Rasa Aman Bagi Penumpang.
e. Tarif yang Jelas
f.Praktis dan Mudah..
g. Gratis Alat Pelindung. ${ }^{4}$
h. Menerima Pengiriman Barang.

\section{i. Kekurangan.Angkutan Berbasis Online}

Kementerian Perhubungan melarang operasi bisnis angkutan penumpang berbasis online, seperti ojek dan taksi. Angkutan yang dikoordinasi oleh perusahaan, seperti Go-Jek dan GrabBike dianggap menyalahi aturan lalu lintas tentang

\footnotetext{
3 https://www.scribd.com/document/286110981/Go-Jek, diakses tanggal 22 Sepetember 2016 2016

${ }^{4}$ www.kalvinliang.com/kelebihan-ojek-online-gojek diakses tanggal 22 September
} 
pemanfaatan sepeda motor."Pengoperasian kendaraan untuk angkutan penumpang umum yang tidak sesuai aturan itu melanggar hukum.Pengoperasiannya dilarang," kata Direktur Jenderal Perhubungan Darat Kementerian Perhubungan Djoko Sasono dalam pesan instan pada Kamis, 17 Desember 2015. ${ }^{5}$

Berlandaskan latar belakang tersebut, maka kami mengambil judul Tesis ini Kajian Teoritis Pemanfaatan Aplikasi Angkutan Berbasis Online Ditinjau Dari Undang-Undang No.8 Tahun 1999 Tentang Perlindungan Konsumen Berkaitan Dengan Undang-Undang No.11 Tahun 2008 Tentang Informasi Transaksi Elektronik.

\section{PERMASALAHAN}

Berdasarkan latar belakang masalah, maka penulis mengidentifikasikan permasalahan-permasalahan sebagai berikut: 1. Upaya meminimasalisir kerugian baik meteriil maupun immaterial oleh perusahaan dan mitra usaha ditinjau dari Undang-Undang Nomor 8 Tahun 1999 Tentang Perlindungan Konsumen.

2. Upaya mengatasi Kendala-kendala yang dihadapi dalam pemanfaatan Aplikasi Angkutan Berbasis Online di tinjau dari Undang-Undang Nomor 11 Tahun 2008 Tentang ITE (Informasi dan Transformasi Elektronik)

5 ttps://m.tempo.co/read/news/2015/12/18/090728739/go-jek-dan-grabbike-dilarangini-alasan-pemerintah diakses 23 September 2016 


\section{PEMBAHASAN}

\section{Tinjauan Umum Terhadap Perlindungan Konsumen.}

Dalam Black's Law Dictionary, pengertian konsumen diberi batasan yaitu:“... A person who buys goods or services for personal family or househlduse, with no intention of resale; a natural person who uses products for personal rather than business purpose"6"Konsumen adalah setiap orang pemakai barang dan/atau jasa yang tersedia dalam masyarakat, baik bagi kepentingan diri sendiri, keluarga,, orang lain, maupun makhluk hidup lain dan tidak untuk diperdagangkan." 7 Konsumen dan produsen merupakan para pihak yang tidak dapat dipisahkan dalam kegiatan bisnis.

\section{Batasan Hukum Perlindungan Konsumen}

Istilah atau pengertian hukum konsumen dengan hukum perlindungankonsumen merupakan istilah yang sering disamaartikan.Ada yangmengatakan hukum konsumen adalah juga hukum perlindungan konsumen.Namun ada pula yang membedakannya, dengan mengatakan bahwa baik mengenai substansi maupun mengenai penekanan luas lingkupnya adalahberbeda satu sama lain ${ }^{8}$

Perlindungan konsumen adalah segala upaya yang menjamin adanya kepastian hukum untuk memberi perlindungan kepada konsumen. ${ }^{9}$ Baik penge ${ }_{35}$ 'ukum konsumen maupun

${ }^{6}$ Bryan A. Garner, Black's Law Dictionary, Eight Edition, 2004, ( St. Paul Minnesota, West Publishing ), 2004,hal. 335.

${ }^{7}$ Pasal 1 angka 2 Undang-Undang Nomor 8 Tahun 1999 Tentang Perlindungan Konsumen

${ }^{8} 5$ N.H.T Siahaan, Hukum Konsumen dan Perlindungan Konsumen, (Jakarta, Panta Rei,), 2005. hlm 30.

${ }^{9}$ Pasal 1 angka 1 Undang-undang Nomor 8 tahun 1999 Tentang Perlindungan Konsumen 
hukum perlindungan konsumen ternyata belum dibakukan menjadi suatu pengertian yang resmi, baik dalam peraturan perundang-undangan maupun dalam kurikulum akademis.Fakultas Hukum Universitas Indonesia mempergunakan hukum perlindungan konsumen, tetapi Hondius, ahli hukum konsumen dari Belanda menyebutnya dengan hukum konsumen (konsumenten recht). 10 Menurut pandangan lain bahwa perlindungan konsumen adalah istilah yang dipakai untuk menggambarkan perlindungan hukum yang diberikan kepada konsumen dalam usahanya untuk memenuhi kebutuhannya dari hal-hal yang dapat merugikan konsumen itu sendiri.11

\section{Asas Perlindungan Konsumen.}

Di dalam ketentuan Pasal 2 Undang-undang Perlindungan Konsumen terdapat lima asas yakni sebagai berikut:
a. Asas manfaat.
b. Asas keadilan.
c. Asas keseimbangan.
d. Asas keamanan dan keselamatan konsumen.
e. Asas kepastian hukum.

Memperhatikan substansi Pasal 2 Undang-Undang Nomor 8 Tahun 1999 Tentang Perlindungan Konsumen demikian pula penjelasannya, tampak bahwa perumusannya mengacu pada filosofi pembangunan nasional yaitu pembangunan manusia Indonesia seutuhnya yang berlandaskan pada falsafah Negara Republik Indonesia. Kelima asas yang disebutkan dalam pasal

${ }^{10}$ Celina Tri Siwi Kristiyanti, Hukum Perlindungan Konsumen, (Jakarta, Sinar Grafika), 2011,hlm 9.

${ }^{11}$ Janus Sidabalok, Hukum Perlindungan Konsumen di Indonesia, (Bandung, Citra Aditya Bakti), 2006, hlm.31. 
tersebut, bila diperhatikan substansinya, dapat dibagi menjadi 3 (tiga) asas yaitu :

1. Asas kemanfaatan yang didalamnya meliputi asas keamanan dan keselamatan konsumen.

2. Asas keadilan yang didalamnya meliputi asas keseimbangan, dan

3. Asas kepastian hukum. ${ }^{12}$

\section{Tujuan Perlindungan Konsumen,}

Sebagaimana termaksud dalam ketentuan Pasal 3

Undang-undang Perlindungan Konsumen adalah:

a. Meningkatkan kesadaran, kemampuan dan kemandirian konsumen untuk melindungi diri;

b. Mengangkat harkat dan martabat konsumen dengan cara menghindarkannya dari ekses negatif pemakaian barang dan/atau jasa;

c. Meningkatkan pemberdayaan konsumen dalam memilih, menentukan, dan menuntut hak-haknya sebagai konsumen;

d. Menciptakan sistem perlindungan konsumen yang mengandung unsur kepastian hukum dan keterbukaan informasi serta akses untuk mendapatkan informasi;

e. Menumbuhkan kesadaran pelaku usaha mengenai pentingnya perlindungan konsumen sehingga tumbuh sikap yang jujur dan bertanggungjawab dalam berusaha;

f. Meningkatkan kualitas barang dan/atau jasa yang menjamin kelangsungan usaha produksi barang dan/atau

${ }^{12}$ Ahmadi Miru \& Sutarman Yodo, Hukum Perlindungan Konsumen, (Jakarta, Raja Grafindo Persada), 2004, hlm 2 
jasa, kesehatan, kenyamanan, keamanan, dan keselamatan konsumen.

\section{Hak Dan Kewajiban Konsumen.}

\section{Hak Konsumen.}

Konsumen menurut Undang-undang Perlindungan Konsumen dalam Pasal 1 angka (2) yaitu Konsumen adalah setiap orang pemakai barang/jasa yang tersedia dalam masyarakat, baik bagi kepentingan diri sendiri, keluarga, orang lain, maupun makhluk hidup lain dan tidak untuk diperdagangkan. Istilah "Perlindungan konsumen"berkaitan dengan perlindungan hukum.Oleh karena itu, perlindungan konsumen mengandung aspek hukum.Adapun materi yang mendapatkan perlindungan itu bukan sekadar fisik, melainkan terlebih-lebih hakhaknya yang bersifat abstrak. Dengan kata lain, perlindungan konsumen sesungguhnya identik dengan perlindungan yang diberikan hukum tentang hak-hak konsumen. ${ }^{13}$ Secara umum dikenal ada 4 (empat) hak dasar konsumen yaitu:

1) Hak untuk mendapatkan keamanan (the right to safety);

2) Hak untuk mendapatkan informasi (the right tobe informed);

3) Hak untuk memilih (the right to choose);

4) Hak untuk didengar (the right tobe heard).

${ }^{13}$ Celina Tri Siwi Kriatiyanti, 2011, Hukum Perlindungan Konsumen, (Jakarta, Sinar Grafika Offset), 2011, hlm 303 


\section{Kewajiban Konsumen}

Kewajiban Konsumen membaca atau mengikuti petunjuk informasi dan prosedur pemakaian atau pemanfaatan barang dan/atau jasa demi keamanan dan keselamatan, merupakan hal penting yang harus mendapat perhatian.

\section{Hubungan Konsumen Dengan Pelaku Usaha}

Persoalan hubungan pelaku usaha dengan konsumen biasanya dikaitkan dengan produk barang dan atau jasa yang dihasilkan oleh teknologi, khususnya teknologi manufaktur dan teknologi informasi. 14

Hubungan pelaku usaha dengan konsumen dapat terjadi secara langsung maupun tidak langsung. Hubungan langsung dapat terjadi apabila antara pelaku usaha dengan konsumen langsung terikat karena adanya perjanjian yang mereka buat atau karena ketentuan undang-undang. Apabila hubungan itu terjadi dengan perantaraan pihak lain, maka terjadi hubungan tidak langsung. Hubungan antara pelaku usaha dengan konsumen pada dasarnya berlangsung terus-menerus dan berkesinambungan karena keduanya saling membutuhkan dan saling interdependensi. ${ }^{15}$

\section{Hak dan Kewajiban Pelaku Usaha}

Dunia usaha harus mampu menghasilkan berbagai barang dan atau jasa yang dapat meningkatkan kesejahteraan masyarakat banyak dengan pemastian terhadap mutu, jumlah yang

14 http://ekakeropoh.blogspot.com/2012/10/pengertian-konsumen-ciri-cirikonsumen.html, diakses Senin,3Oktober 2016 pukul 12.20

15 Janus Sidabalok, Op. Cit., hlm. 15 
mencukupi, serta keamanan pada pemakaian barang dan atau jasa yang diedarkan ke pasar. Pelaku usaha merupakan salah satu komponen yang turut bertanggung jawab dalam mengusahakan tercapainya kesejahteraan rakyat itu. Maka di dalam berbagai peraturan perundang-undangan dibebankan sejumlah hak dan kewajiban serta hal-hal yang menjadi tanggung jawab pelaku usaha. Dalam kegiatan menjalankan usaha, Undang-Undang memberikan sejumlah hak dan membebankan sejumlah kewajiban dan larangan kepada pelaku usaha. Pengaturan tentang hak, kewajiban, dan larangan itu dimaksudkan untuk menciptakan hubungan yang sehat antara pelaku usaha dan konsumen. ${ }^{16}$

\section{Legalitas Transaksi e-Commerse.}

Perkembangan teknologi informasi yang revolusioner bertumpu pada istilah yang disebut sebagai "informasi elektronik", yang menjadi "nucleus" atau bahkan "nuclei" dari teknologi itu. ${ }^{17}$ Istilah informasi elektronik terdiri dari dua term yaitu "informasi" dan "elektronik".Dari sisi terminology berarti masih ada informasi yang "non elektronik". Dalam perkembangan literature terdapat varian yang cukup banyak tentang definisi "informasi" Inggris yakni on" dengan kata dasar "inform" yang secara leksikal artinya to give,imbue or inspire with some specific quality or character". Jadi informasi bukan hanya sebagai suatu objek ataupun output saja, yang lazim diartikan dalam pengertian bahasa sebagai suatu keterangan ataupun berita, melainkan yang penting terletak pada

\footnotetext{
${ }^{16}$ Undang-Undang Nomor 8 Tahun 1999 Tentang Perlindungan Konsumen.

${ }^{17}$ Ahmad M Ramli, Menuuju Kepsatian Hukum di Bidang Informasi dan Hukum di Bidang Informasi Dan Transaksi Elektronik, ( Jakarta, Departemen Komunikasi Dan Informatika Republik Indonesia), 2007, hlm 35
} 
pemrosesannya dalam arti bahwa informasi dikatakan benar, ada, terjadi, aspek validitasnya terletak bila informasi itu dapat dipertanggungjawabkan secara teknis. 18 Definisi "informasi" disampaikan oleh Gordon B.Davis Menurut Gordon B. Davis (1984:200), "Information is data that has been processed into a form that is meaningful to the recipient and is of real or perceived value in current or prospective actions or decisions" di definisi kan sebagai Informasi adalah data yang telah diproses/diolah ke dalam bentuk yang sangat berarti untuk penerimanya dan merupakan nilai yang sesungguhnya atau dipahami dalam tindakan atau keputusan yang sekarang atau nantinya. ${ }^{19}$

E-commerce dapat dipahami sebagai kegiatan transaksi perdagangan baik barang dan jasa melalui media elektronik yang memberikan kemudahan didalam kegiatan bertransaksi konsumen di internet. ${ }^{20}$ Keunggulan e-commerce terletak pada efisiensi dan kemudahannya, membahas tentang hukum e-commerce maka tidak akan lepas dari hukum internet (cyber law). Internet adalah dunia virtual/dunia maya yang memiliki komunitas yang sangat khas, yaitu tentang bagaimana aplikasi teknologi komputer yang berlangsung secara online pada saat si pengguna internet menekan atau telah terkoneksi dengan jaringan yang ada.Maka dalam konteks ini pula maka aspek hukum yang melekat dari mekanisme e-commerce adalah berinteraksi dengan aplikasi jaringan internet yang digunakan oleh pihak yang melakukan transaksi melalui

\footnotetext{
${ }^{18}$ Ibid, hlm 36

${ }^{19}$ Gordon B. Davis, Kerangka Dasar Sistem Informasi Manajemen Bagian 1, (Jakarta, PT Pustaka Binamas Pressindo ),1991, hlm 28

${ }^{20}$ Michael ,Understansing Electronic Commerce From A Historitical Perspective, http://www.oecd.org/dsti/sti/it/infosoc/, diakses tanggal 3 Februari 2008
} 
system e-commerce. ${ }^{21}$ Pengertian Transaksi Elektronik istilah Electronic Commerce belum memiliki istilah yang baku. Terdapat beberapa istilah yang dikenal pada umumnya seperti $E$-Commerce, WEB Contract, dan Kontrak Dagang Elektronik. Namun dalam tulisan ini, istilah yang digunakan adalah e-commerce.

Sebagimana yang telah diuraiakan sebelumnya bahwa perjanjian dalam transaksi elektronik berbentuk perjanjian baku/standard transaksi tersebut dilandasi dengan adanya "Konsep Hukum Sistem Terbuka"yang diatur dalam Pasal 1338 ayat (1) KUHPerdata.Konsep ini dikenal dari kalimat "semua perjanjian mengikat sebagai Undang-Undang bagi mereka yang membuatnya”.Selanjutnya dikenal sebagai asas kebebasan berkontrak. Dengan asas ini memberikan kedudukan kedua belah pihak pada posisi sama kuat dalam melakukan sautu perjanjian.Pasal 1338 ayat (1) KUHPerdata yang merupakan tiangnya pengembangan Hukum perjanjian, berkaitan dengan penjabaran dari asas kebebasan berkontrak tersebut yaitu:

1. Bebas membuat jenis perjanjian apapun,

2. Bebas mengatur isinya,

3. Bebas mengatur bentuknya.

Dengan demikian perjanjian dalam transaksi-transaksi elektronik mempunyai dasar hukum yang kuat yaitu Pasal 1338 KUHPerdata.

Meminimalisir Kerugian Baik Materil Maupun Immateriil oleh Pengusaha Dan Mitra Usaha Ditinjau Dari Undang-Undang Nomor.8/1999 Tentang Perlindungan Konsumen. 
Perubahan sosial merupakan suatu wujud dinamika yang menjadi inti jiwa masyarakat.Masalah perubahan sosial menjadi topik yang menarik bagi banyak sosiolog modern, terutama dalam hubungannya dengan pembangunan ekonomi yang diusahakan oleh banyak masyarakat negara-negara yang memperoleh kemerdekaan politiknya setelah Perang Dunia II.Perubahan sosial itu didorong oleh rangsangan terhadap kemauan untuk bertindak.

Perkembangan bisnis saat ini tidak terlepas dari peran penting teknologi informasi. Dengan berkembangnya teknologi informasi, kekuatan informasi dan teknologi informasi dijadikan sebagai alat / tools dalam memenangkan persaingan/ kompetisi bisnis. Teknologi informasi dan komunikasi (TIK) mencakup dua aspek, yaitu teknologi informasi dan teknologi komunikasi. Teknologi informasi, meliputi segala hal berkaitan dengan proses, penggunaan sebagai alat bantu, manipulasi, dan pengelolaan informasi. Teknologi komunikasi merupakan segala hal yang berkaitan dengan penggunaan alat bantu untuk memproses dan mentransfer data dari perangkat yang satu ke lainnya. Karena itu, teknologi informasi dan teknologi komunikasi adalah suatu padanan yang tidak terpisahkan yang mengandung pengertian luas tentang segala kegiatan yang terkait dengan pemprosesan, manipulasi, pengelolaan, dan transfer/ pemindahan informasi antar media. ${ }^{22}$

\section{KESIMPULAN}

a. Pemanfaatan teknologi informasi oleh pebisnis angkutan berbasis online berkerjasama dengan mitra kerja memanfaatkan jaringan yang luas sampai ke daerah-

${ }^{22}$ Buletin Pos dan Telekomunikasi Volume 10 No.1, 2012. 
daerah. Tentunya dibarengi juga dengan menyediakan perangkat dan jaringan di internal perusahaannya masingmasing, sehingga dapat terhubung dan terkontrol secara online.

Untuk meminimalisir kerugian baik materil maupaun immaterial sebagai akibat peristiwa “ force majeur' seperti kerusuhan, bencana alam, Pengusaha perlu memberikan asuransi sebagai payung hukum bagi Pengusaha terhadap mitra usaha, begitu juga sebaliknya mitra usaha terhadap pengusaha, dan Pengusaha terhadap Kosumen pengguna langsung angkutan berbasis online, hendaknya mereka dipertanggungkan terhadap resiko-resiko ini terhadap lembaga asuransi wajib dan asuransi swasta sebagai tambahan /pelengkap, sehingga kenyamanan semua pihak (Pengusaha, mitra usaha dan konsumen) dan eksistensi usaha dapat diperolah dengan paripurna. Kendala yang dihadapi dalam pemanfaatan aplikasi teknologi informasi dalam bisnis angkutan antara lain pengadaan perangkat teknologi informasi dan membuat jaringan di internal perusahaan cukup signifikan biaya yang diperlukan.

b. Pemerintah perlu menyiapkan regulasi yang diperlukan untuk melindungi pengusaha, mitra usaha dan konsumen dalam $\mathrm{e}^{-}$ commerce secara rigid dan comprehenship juga visioner. Sehingga secara Nasional bisa digunakan tanpa harus mengacu secara mutlak pada aturan dan kebijakan Negara lain, Hal yang mungkin akan menjadi kendala ketika konsumen melakukan jual beli barang dan atau jasa melalui internet meminta pertangung jawaban yaitu perbedaan/ jarak antara pelaku usaha dengan konsumen, waktu 
ganti rugi singkat, Kelemahan UU, kurangnya pengetahuan konsumen tentang Perlindungan konsumen.

Secara materi (isi) Kitab Undang-Undang Hukum Perdata dan Undang -Undang Perlindungan Konsumen belum secara tegas mengatur tanggung jawab pelaku usaha dalam jual beli barang dan jasa melalui internet yang melampaui batas-batas negara yang diatur hanyalah perdagangan secara tradisional konvensional. Begitu pula pada Undang-Undang Teknologi dan Informasi, tidak dengan khusus mengatur tentang jual beli barang dan jasa. Faktor culture budaya masyarakat Indonesia yang kurang memahami tentang hak-hak sebagai konsumen dan tanggung jawab pelaku usaha yang kurang, menyebabkan masalah perlindungan konsumen menjadi hal yang biasa saja.

\section{SARAN}

a. Pertumbuhan pendudukan yang begitu pesat, sementara tidak berbanding lurus dengan lapangan pekerjaan yang tersedia maka peluang tindak kejahatan selalu ada bagi mereka dengan segala alasan dan motiv. Karenanya perlu mendapat perhatian bagi setiap pribadi agar selalu memperhatikan secermat mungkin segala kemungkinan yang akan timbul khususnya berkaiatan dengan fenomena usaha yang relative baru ini yaitu bisnis usaha dengan memanfaatkan aplikasi angkutan berbasis online ini. Persaingan bisnis, gesekan konflik antara angkutan konvensional baik moda roda dua (ojek) ataupun roda empat, dengan angkutan berbasis online.Sebagian pengendara Ojek 
online suka menggunakan alat komunikasi (Hand Phone) saat membawa penumpang, hal ini bisa menyebabkan resiko kecelakaan.

b. Antara kebutuhan hukum dan peraturan bahwa hukum mempunyai asas manfaat, adil, kegunaan, kepastian dan keteraturan. Masyarakat membutuhkan go-jek sebagai alat moda, begitu juga moda roda empat yang kesemuanya itu menggunakan aplikasi berbasis online, karena relatif mudah, praktis, aman dan murah. Khusus peraturan tidak mengaturnya. Hukum memenuhi kebutuhan masyarakat untuk go-jek, dan sejenisnya seperti yang uatkita lihat ada Grabbike dan Uber, moda angkutan roda dua yang belum diatur oleh regulasi pemerintah, seharusnya Kementrian Perhubungan selaku Regulator pemerintah bisa menerbitkan kebijakan hukum yang bisa memberikan solusi.. Kebijakan hukum berfungsi untuk mengisi kekosongan hukum terhadap peraturan yang memang belum mengaturnya. Perlu penataan yang serius terhadap kebijakan harga sehingga tidak menimbulkan konflik terhadap ojek konvensional yang dikarenakan ketidak wajaran harga (relative murah) dan dengan adanya tarif promo di luar kewajaran. Hukum perlu menyesuaikan perkembangan masyarakatnya.

\section{DAFTAR PUSTAKA}

\section{BUKU}

Abdulkadir Muhammad, HukumPerikatan, Bandung, Citra AdityaBakti, 2003 
Abdul.G.Hakim Nusantara dan Nasroen Yasabari, Beberapa Pemikiran Pembangunan Hukum Indonesia, Bandung, Alumni,1980.

Ahmad Miru \& Sutarman Yudo, Hukum Perlindungan Konsumen, Jakarta, Raja GrafindoPersada, 2004.

Ade Maman Suherman, Aspek Hukum Dalam Ekonomi Global, Jakarta, Ghalia Indonesia, 2002.

Aji Supriyanto, Pengantar Teknologi InformasiJ, Jakarta, Salemba Infotek, 2005.

Ahmad M.Ramli, Menuju .Kepastian Hukum di Bidang Informasi dan Hukum di Bidang Informasi Dan Transaksi Elektronik, Jakarta, DepartemenKomunikasi Dan Informatika Republik Indonesia, 2007.

Ahmad Miru \& Sutarman Yudo, Hukum Perlindungan Konsumen, Jakarta, Raja GrafindoPersada, 2004

BagjaWaluya, Pengantar Sosiologi: Pemahaman Fakta dan Gejala Permasalahan Sosial; Teori, Aplikasidan Pemecahannya, Bandung, Setia Purnama Invest, 2004

Bambang Waluyo, Penelitian Hukum Dalam Praktek, Sinar Grafika, Jakarta, 1991.

Bryan A.Garner, Black's Law Dictionary, Eight Edition,West Publishing St.Paul Minnesota, 2004

Caerl Joachim Friedrich, Filsafat Hukum Perspekif Historis, Bandung, Nuansadan Nusamedia, 2004.

Celina Tri Siwi Kristiyanti, Hukum Perlindungan Konsumen, Jakarta, Sinar Grafika, 2011.

Deni Damayanti, Panduan Lengkap Menyusun Proporsal, Skripsi, Tesis, Disertasi, Untuk Semua Program Study, Yogyakarta, Araska, 2013

E.ZaenalArifin, Dasar-Dasar Penulisan Karya Ilmiah, Jakarta, Grasindo, 2010.. 
Janus Sidabalok, Hukum Perlindungan Konsumen di Indonesia, Bandung, Citra AdityaBakti, 2006.

Kuntowijoyo, Islam Sebagai Ilmu: Epistimologi, Metodelogi dan Etika, Bandung Teraju Mizan, 2004.

L.J.Apeldoorn, Pengantar Ilmu Hukum, Jakarta, Pradnya Paramita, 1996

Martin Wolf, Globalisasi Jalan Menuju Kesejahteraan, Freedom Institution, - Yayasan Obor Indonesia, Jakarta, 2007.

M.Sulaeman Jajuli, Kepastian Hukum Gadai Tanah, Yogyakarta, Deep Publish, 2015.

M.T.MisbahYazdi, Daras Filsafat Islam, Orientasike Filsafat Islam Kontemporer, Jakarta, 2010.

Muhammad Taqi Misbah Yazdi, Amuzesy-e Falsafeh,Nasyer-e BainalMilal, Cap-e Haftum, Qom, 1386 S.

Otje Salman dan Eddy Damian, Konsep-KonsepHukumdalam Pembangunan, Bandung,Alumni,

Otje Salman, IhktisarFilsafatHukum, Bandung, Amrico, 1987.

Rachmad Baro, Penelitian Hukum Non Doktrinal, Penggunaan Metodadan Tehnik Penelitian Sosial di Bidang Hukum, Yogyakarta, Deep Publish, 2016.

Romli Atmasasmita, Teori hukum Integratif, Yogyakarta, Genta Publishing, 2012.

Mariam DarusBadrulzaman, KompilasiHukumPerikatan, Bandung, Citra AdityaBakti, 2001.

Undang-Undang

Undang-Undang No. 8 Tahun1999 tentang Perlindungan Konsumen Komisi

Undang-Undang No. 11 Tahun 2008 tentang InformasiTransaksi Elektronik

\section{Website}


http://www.hukumonline.com,"ObjekPraperadilanMenurut KUHAP”, diakses pada tanggal 10 Agustus 2016.

https://www.merdeka.com/jakarta/ceo-go-jek-pengendara-gojek-sudah-10000 orang.html, diakses tanggal 21 Oktober 2016 

